\title{
PENGARUH LINGKUNGAN KERJA, KARAKTERISTIK INDIVIDU DAN DISIPLIN KERJA TERHADAP KINERJA KARYAWAN PT. MITRATANI DUA TUJUH JEMBER
}

\section{EFFECT OF WORK ENVIRONMENT, INDIVIDUAL CHARACTERISTICS AND DISCIPLINE OF WORK ON EMPLOYEE PERFORMANCE PT. TWO SEVEN JEMBER MITRATANI}

\author{
Siti Qibtiatul Hasanah ${ }^{1}$ Seno Sumowo $^{2}$, Budi Santoso ${ }^{3}$ \\ Fakultas Ekonomi Universitas Muhammadiyah Jember ${ }^{123}$ \\ Email: seno.sumowo@ unmuhjember.ac.id dan
}

\begin{abstract}
ABSTRAK
Tujuan penelitian ini adalah untuk mengetahui dan menganalisis pengaruh Lingkungan kerja, Karakteristik Individu dan Disiplin kerja terhadap Kinerja karyawan. Penelitian dilakukan pada karyawan PT. Mitratani Dua Tujuh Jember. Populasi dalam penelitian ini adalah seluruh karyawan PT. Mitratani Dua Tujuh Jember sebanyak 1.654 responden. Teknik pengambilan sampel menggunakan proporsional sampling sebanyak 94 responden.. Teknik pengumpulan data menggunakan wawancara dan kuesioner. Analisis yang digunakan meliputi uji instrumen pengumpulan data (uji validitas dan uji reliabilitas), analisis regresi linier berganda, uji asumsi klasik (uji multikolinieritas, uji heteroskedastisitas, dan uji normalitas) dan uji hipotesis (uji t, dan uji koefisien determinasi). Data olahan menggunakan IBM SPSS 20.0. Hasil analisis menggunakan regresi dapat diketahui bahwa variabel lingkungan kerja, karakteristik individu, dan disiplin kerja berpengaruh signifikan terhadap kinerja karyawan pada Perusahaan PT. Mitratani Dua Tujuh Jember.
\end{abstract}

Kata Kunci : lingkungan kerja, karakteristik individu dan disiplin kerja

\begin{abstract}
The purpose of this study was to determine and analyze the influence of the work environment, individual characteristics, and discipline on employee performance. Research was conducted on employees of PT. Mitratani Dua Tujuh Jember. The population in this study were all empoyees of PT. Mitratani Dua Tujuh Jember totaling 1.654 respondents. The sampling technique used proportional sampling as many as 94 respondents. Data collection techniques using interviews and questionnaires. Alanisi used include test instrument data collection (validity test, reliability test), multiple linear regression analysis, classical assumption test (multicollinearity test, heteroscedasticity test, and normality test), and hypothesis test ( $\mathrm{t}$ test, and determination coefficient test). Processed data using IBM SPSS 20.0. The results of the analysis using regression can be seen that the variables of the work environment, individual characteristics, and work discipline have a significant effect on the formance of employees in the company PT. Mitratani Dua Tujuh Jember
\end{abstract}

Key words : work environment, individual characteristics, work discipline 


\section{PEDAHULUAN}

Sumber daya manusia mempunyai peran penting dalam menentukan keberhasilan suatu organisasi. Dalam kemajuan zaman saat ini, kondisi memaksakan agar semua berjalan serba terarah dan teratur. Hampir semua orang dituntut untuk bekerja secepat mungkin. Namun juga tidak mengurangi kualitas dari apa yang dilakukannya. Segala macam ilmu pengetahuan dan teknologipun juga semakin berkembang agar kebutuhan Sumber Daya Manusia dapat terpenuhi. Keberhasilan-keberhasilan pengembangan segala sesuatu yang telah ada tersebut tidak lepas dari adanya SDM (Sumber Daya Manusia) yang memadai, berkualitas dan dapat beradaptasi dengan kondisi lingkungan sekitar. Oleh karena itu kinerja adalah hasil secara kualitas dan kuantitas yang dapat dicapai oleh seseorang karyawan dalam melaksanakan tugas sesuai dengan tanggung jawab yang diberikan kepadanya (Mangkunegara, 2013).

Sumber daya manusia ini merupakan kunci pokok dalam sebuah organisasi. Faktor manusia dalam administrasi memegang peranan yang sangat penting dan menentukan, karena selain manusia memiliki rasio dan persamaan sebagai makhluk ciptaan Tuhan Yang Termulia. Juga sangat penting dan merupakan peranan yang dorminan, karena unsur-unsur lainnya yang dimiliki organisasi seperti: uang, mesin, material, metode kerja, waktu dan kekayaan lainnya hanya dapat memberi manfaat bagi manusia apabila manusia merupakan faktor perangsang kearah tercapainya tujuan organisasi secara efisien, efektif dan ekonomis (Efendy, 2012).

Tujuan organisasi akan tercapai apabila memiliki sumber daya yang mumpuni dan didukung oleh sumber daya manusia yang mempunyai kerja yang optimum. Hal ini menunjukkan bahwa sumber daya manusia merupakan kunci pokok yang harus diperhatikan dengan segala kebutuhan penunjangnya Siagian, (2011). Melihat dari pentingnya peranan sumber daya manusia dalam organisasi, maka sumber daya manusia harus dikelola dengan baik. Begitu halnya dalam suatu perusahaan, dimana banyak konsumen atau pelanggan yang membutuhkan produk mereka. Untuk itu seorang pimpinan perusahaan juga harus memikirkan tingkat kinerja karyawan.

Menurut Simomara (2004) kinerja adalah proses yang dipakai oleh organisasi untuk mengevaluasi pekerjaan individu karyawan. Menurut Peoni (2014) dalam penelitian yang dilakukannya, kinerja akan terpengaruh oleh beberapa factor yang memiliki pengaruh pada kinerja diantaranya seperti lingkungan dan karakteristik 
individu. Disisi lain lingkungan kerja juga akan mendukung tingkat kerja para karyawan. Lingkungan dianggap penting, karenanya seorang pimpinan perlu memahami sifat lingkungan kerja tempat berlangsungnya kegiatan yang mengarah pada pencapaian tujuan dan harus mampu mengubahnya bila perlu dilakukan guna menciptakan suasana yang lebih tepat bagi usaha untuk meningkatkan kinerja karyawan (Siagian, 2005).

Lingkungan kerja yang memuaskan karyawan tentu akan meminimalisir atau menekan kerja karyawan untuk mencapai kinerja yang memuaskan bagi perusahaan. Begitu juga sebaliknya, keadaan lingkungan kerja yang nyaman, aman dan mendukung akan membuat karyawan baik yang berada dibagian produksi semakin ramah, bersemangat dan bergairah dalam melayani konsumen dan juga masyarakat sekitarnya. Hal ini dapat memberi pengaruh positif bagi kondisi psikologis karyawan. Menurut Mangkunegara (2004), lingkungan kerja mempunyai hubungan yang sangat erat terhadap kinerja karyawan, motif berprestasi yang perlu dimiliki oleh karyawan harus ditumbukhan dari dalam diri sendiri dan lingkungan kerja, karena motif berprestasi yang ditumbuhkan dari dalam diri sendiri akam membentuk suatu kekuatan diri dan jika situasi lingkungan kerja turut menunjang maka pencapaian kinerja akan lebih mudah.

Perusahaan dalam mencapai tujuannya tidak mungkin mengoprasikan kegiatannya tanpa adanya manusia karena fakror tenaga kerja manusia memegang peranan yang sangat penting dalam pencapaian tujuan perusahaan. Setiap manusia mempunyai watak dan perilaku yang berbeda, disebabkan karena beberapa hal, misalnya latar belakang pendidikan, ketrampilan, watak dasar maupun factor-faktor lainnya dari tenaga itu sendiri. Keberagamaan perilaku tersebut akan mempengaruhi jalannya perusahaan, yang bukan saja berdampak pada hasil yang dicapai perusahaan, tetapi juga bagi masyarakat yang membutuhkan produk perusahaan tersebut. Keberagaman perilaku tersebut dapat juga disebut karakteristik individu seperti yang disebutkan oleh Stoner dalam Simamora, (2004) bahwa karakteristik individu adalah keinginan, sikap dan kebutuhan seseorang yang dibawa kedalam situasi kerja. Suatu perusahaan bagaimanapun majunya teknologi yang dimiliki tanpa ditunjang dengan dan oleh tenaga kerja yang cakap maka kemungkinan besar sasaran dari perusahaan tidak akan tercapai. Tenaga kerja yang bekerja sesuai dengan fungsinya (the right man in the right place) akan menunjang tercapainya keberhasilan tujuan perusahaan. 
Aspek lain yang mempengaruhi kinerja karyawan adalah kedisiplinan. Kedisiplinan memegang peranan yang amat penting dalam pelaksanaan kerja pegawai. Pegawai yang mempunyai disiplin akan menaati peraturan yang ada pada lingkungan kerjanya dengan kesadaran yang tinggi tanpa ada paksaan. Kedisiplinan adalah kesadaran dan kesediaan seseoarang dalam mentaati semua peraturan organisasi dan norma sosial yang berlaku (Hasibuan, (2002:193).

Menurut Nawawi (2013), mengatakan bahwa seorang karyawan dikatakan baik, jika selama jam kerja yang bersangkutan selalu tekun, tidak pernah membolos, datang dan pulang tepat waktunya, mengerjakan pekerjaan dengan daya guna, pekerjaan diselesaikan tepat waktu dan sebagainya. Triyaningsih (2014) diketahui bahwa disiplin kerja berpengaruh positif dan signifikan terhadap kinerja karyawan. Sama halnya seperti penelitian yang telah dilakukan oleh Triwibono dan Zamora (2016) bahwa disiplin kerja berpengaruh positif dan signifikan terhadap kinerja karyawan

Berdasarkan peneliti terdahulu yang telah dipaparkan diatas maka, peneliti menyimpulkan bahwa lingkungan kerja berpengaruh terhadap kinerja karyawan. Jika lingkungan kerja pada suatu perusahaan baik dan terjamin, maka karyawan akan lebih nyaman bekerja dan bergairah sehingga menghasilkan kinerja yang baik, begitu pula sebaliknya. Jika karaktersitik yang tertanam baik seperti etika dan cara berkomunikasi dengan baik dengan karyawan lain maka akan menimbulkan suasana kerja yang nyaman dan menimbulkan suatu kekompakan dan semangat kerja sehingga kinerja karyawan akan meningkat dan membaik.

PT Mitratani Dua Tujuh, merupakan salah satu anak perusahaan PTPN X yang bergerak secara khusus dalam industri sayuran beku terutama edamame. Namun saat ini sudah berkembang sehingga juga memproduksi okra, bunchis, jagung dan wortel. Berdasarkan anggaran dasar perusahaan, ruang lingkup kegiatan perusahaan bergerak dalam bidang agorindustri dan perdagangan dengan komoditi utama kedelai jepang atau Edamame. Pabrik dan kantor perusahaan berlokasi di jalan brawijaya No. 83, Kelurahan Desa Mangli, Kecamatan Kaliwates, Kabupaten Jember, Jawa Timur.

PT. Mitratani Dua Tujuh melakukan proses produksi edamame dari penanaman edamame hingga siap di pasarkan sesuai dengan permintaan dan segmentasi pasar. Agar dapat menghasilkan produk yang optimal sesuai permintaan para konsumen, PT. 
Mitratani Dua Tujuh membutuhkan karyawan yang dapat bekerja secara efektif dan efisien. Agar tujuan perusahaan tercapai, karyawan harus mempunyai kinerja yang baik.

Tabel 1. Daftar Perusahaan Edamame yang Berada di Jember

\begin{tabular}{llll}
\hline No & \multicolumn{1}{c}{ Nama Perusahaan } & Alamat & Kapasitas Produksi/th \\
\hline 1 & PT. Mitratani Dua Tujuh Jember & Mangli & $6.200 /$ th \\
2 & PT. Gading Mas Indonesia Teguh & Ajung & $1.600 /$ th \\
\hline
\end{tabular}

Sumber data: PT. Mitratani Dua Tujuh Jember (2018)

Tabel 1.1 menunjukkan perusahaan yang memproduksi edamame yang berada dikabupaten Jember beserta kapasitas produksi per tahun, maka peneliti disini berfokus pada perusahaan No 1, karena perusahaan tersebut merupakan perusahaan paling besar dikabupaten Jember. Disini peneliti berusaha meneliti perusahaan tersebut karena semakin besar perusahaan, semakin besar pula pengaruh lingkungan kerja, karaktersitik individu dan disisiplin kerjanya.

Berdasarkan hasil wawancara yang telah dilakukan terhadap karyawan PT. Mitratani Dua Tujuh peneliti mendapatkan beberapa indikasi terkait lingkungan kerja, karakteristik individu dan disiplin kerja. Pertama terkait dengan lingkungan kerja yang meliputi kebersihan tempat kerja yang meliputi tidak adanya kotoran, sampah maupun debu yang mengganggu di sekitar tempat kerja karyawan, pencahayaan atau cahaya lampu penerangan maupun cahaya matahari dapat masuk secara langsung sehingga udara yang didalam dapat bertukar dengan bebas dengan udara yang diluar dan minimnya suara yang keras yang berasal dari jalan raya, aktivitas kerja lain, pasar dan lain sebagainya. Lingkungan kerja yang nyaman, aman dan tentram akan membuat karyawan tenang dalam bekerja serta karyawan lebih fokus dan tidak terganggu, karena semakin nyaman karyawan dalam bekerja maka karyawan dapat kerja dengan maksimal semangat dalam bekerja akan bertambah. Begitupula sebalikanya jika tempat kerja kurang nyaman bagi karyawan maka karyawan akan malas dan tidak betah berkerja yang akan berakibat pada kinerja karyawan tersebut.

Kedua mengenai karateristik individu terdapat beberapa indiksasi yang diperoleh karyawan PT. Mitratani Dua Tujuh. Setiap karyawan mempunyai latar pendidikan yang berbeda - beda sehingga menimbulkan kemampuan yang dimiliki oleh masing - masing . Kemampuan tersebut dibawa kedunia kerja sehingga dapat diaplikasikan ketika melakukan suatu pekerjaan-pekerjaan yang didasari kemampuan akan menghasilkan 
kerja yang baik sehingga kinerja karyawan akan semakin baik. Karyawan juga bersal dari berbagai kalangan mempunyai watak dan sifat yang berbeda. Dalam hal itu setiap karyawan harus memperhatikan betul etika dan cara berkomunikasi dengan baik kepada karyawan lain, dapat berkomunikasi dan berperilaku yang baik dengan keryawan lain saat bekerja akan menimbulkan suasana kerja yang baik kerena karyawan dapat saling membaur dan menimbulkan suatu kekompakan dan semangat kerja sehinggan kinerja karyawan akan meningkat dan membaik. Dan yang terakhir terkait mengenai disiplin kerja yang meliputi ketepatan waktu karyawan untuk bekerja baik jam masuk kerja ataupun pulang kerja, tanggung jawab yang masih kurang, kurangnya ketaatan terhadap aturan perusahaan dan masih banyak yang tidak membuat surat ijin bila tidak masuk kerja.

Kinerja karyawan PT. Mitratani Dua Tujuh Jember dapat dikatakan belum optimal . dikarenakan masih terdapat beberapa target ekspor edamame yang masih belum tercapai. Jika terjadi penurunan kinerja karyawan setiap tahunnya maka akan berdampak negative bagi perusahaan karena dapat menghambat eksistensi dari perusahaan itu sendiri.

Berdasarkan latar belakang diatas dan untuk lebih menunjang dalam penelitian kali ini, maka peneliti mencoba membuat rumusan masalah sebagai berikut:

1) Apakah lingkungan kerja berpengaruh secara signifikan terhadap kinerja karyawan pada Perusahaan Mitratani Dua Tujuh Jember?

2) Apakah karakteristik individu berpengaruh secara signifikan terhadap kinerja karyawan pada Perusahaan Mitratani Dua Tujuh Jember?

3) Apakah disiplin kerja berpengaruh secara signifikan terhadap kinerja karyawan pada Perusahaan Mitratani Dua Tujuh Jember?

Berdasarkan identifikasi rumusan masalah tersebut maka tujuan penelitian ini adalah sebagai berikut:

1. Untuk menganalisa pengaruh lingkungan kerja secara signifikan terhadap kinerja karyawan di Perusahaan Mitratani Dua Tujuh Jember.

2. Untuk menganalisa pengaruh karakteristik individu secara signifikan terhadap kinerja karyawan di Perusahaan Mitratani Dua Tujuh Jember.

3. Untuk menganalisa pengaruh disiplin kerja secara signifikan terhadap kinerja karyawan di Perusahaan Mitratani Dua Tujuh Jember. 


\section{TINJAUAN PUSTAKA}

\section{Manajemen Sumber Daya Manusia}

Memahami pentingnya keberadaan SDM (Sumber Daya Manusia) di era global saat ini salah satu upaya yang harus dicapai oleh perusahaan adalah dengan meningkatkan kualitas SDM (Sumber Daya Manusia). Dengan meningkatkan kualitas sumber daya manusia diharapkan karyawan dapat meningkatkan kinerjanya.Kinerja karyawan merupakan suatu tindakan yang dilakukan karyawan dalam melaksanakan pekerjaan yang diberikan perusahaan Handoko, (2008). Setiap perusahaan selalu mengharapkan karyawannya mempunyai prestasi, karena dengan memiliki karyawan yang berprestasi akan memberikan sumbangan yang optimal bagi perusahaan. Selain itu, dengan memiliki karyawan yang berprestasi perusahaan dapat meningkatkan kinerja perusahaannya.

\section{Kinerja Karyawan}

Kinerja merupakan hasil kerja secara kualitas maupun kuantitas yang dicapai oleh seorang pegawai dalam melaksanakan tugasnya sesuai dengan tanggung jawab yang diberikan padanya. Kinerja pegawai merupakan tujuan akhir dan merupakan cara bagi manajer untuk memastikan bahwa aktivitas pegawai dan output yang dihasilkan sinergi dengan tujuan organisasi (Mangkunegara, 2008). Kinerja adalah proses yang dipakai oleh organisasi untuk mengevaluasi pekerjaan individu karyawan Simamora, (2004). Sedangkan menurut Hasibuan (2000) menyatakan bahwa kinerja adalah hasil yang dicapai seseorang dalam melaksanakan tugas - tugas yang dibebankan kepadanya berdasarkan kecakapan, pengalaman dan kesungguhan. Kinerja karyawan merupakan bentuk sikap sehari-hari yang dilakukan karyawan untuk mencapai tujuan perusahaan Kinerja karyawan perlu dilakukan evaluasi secara berkala (Azhad. Dkk. 2015).

\section{Lingkungan Kerja}

Lingkungan kerja merupakan salah satu hal penting yang harus diperhatikan oleh perusahaan. Menurut (Nitisemito, 2003) Lingkungan kerja adalah segala sesuatu yang ada disekitar karyawan dan dapat mempengaruhi dalam menjalankan tugas yang diembankan kepadanya misalnya dengan adanya air conditioner $(A C)$, penerangan yang memadai dan sebagainya.

Menurut Sedermayanti (2009) kondisi lingkungan kerja dikatakan baik atau sesuai apabila manusia dapat melaksanakan kegiatan secara optimal, sehat, aman dan 
nyaman.Jenis lingkungan kerja dibagi menjadi dua yaitu lingkungan kerja fisik dan lingkungan kerja non fisik.Lingkungan kerja fisik yaitu semua keadaan berbentuk fisik yang terdapat disekitar tempat kerja dimana dapat mempengaruhi karyawan baik secara langsung maupun tidak langsung.

\section{Karakteristik Individu}

Sumber daya yang memiliki pengaruh paling penting dalam sebuah organisasi adalah sumber daya manusia yaitu orang-orang yang memberikan tenaga, bakat, kreatifitas dan usaha mereka kepada organisasi agar dapat tetap pada eksistensinya. Setiap manusia mempunyai karakteristik individu yang berbeda-beda antara yang satu dengan yang lain. Menurut Stoner dalam (Simamora, 2004) karakteristik individu adalah keinginan, sikap dan kebutuhan seseorang yang dibawa ke dalam situasi kerja. Lebih lanjut Robbins mengemukakan bahwa variabel ditingkat individu meliputi karakteristik biografis yang didalamnya berisi seputar kemampuan, kepribadian serta pembelajaran. Sedangkan karakteristik biologis meliputi usia, jenis kelamin, status perkawinan, banyaknya tanggungan, dan masa kerja dengan suatu organisasi itu sendiri.

\section{Disiplin Kerja}

Kedisiplinan lebih tepat diartikan sebagai suatu tingkah laku dan perbuatan yang sesuai dengan peraturan perusahaan baik tertulis maupun tidak. Dalam prakteknya sulit untuk mengusahakan seluruh praturan ditaati untuk setiap karyawan. Adanya kedisiplinan diharapkan pekerjaan dapat dilakukan secara efektif dan efisien.

Disiplin kerja seperti yang dikemukakan oleh Rivai (2011) adalah suatu alat yang digunakan para manajer untuk berkomunikasi dengan karyawan agar mereka bersedia mengubah suatu peerilaku serta sebagai suatu upaya untuk meningkatkan kesadaran dan kesediaan seseorang mentaati peraturan perusahaan dan norma - norma sosial yang berlaku. Hodges (2010) mengatakan bahwa disiplin dapat diartikan sebagai sikap seseorang atau kelompok yang berniat untuk mengikuti aturan - aturan yang telah ditetapkan. Dalam kaitannya dengan pekerjaan, pengertian disiplin kerja adalah suatu sikap dan tingkah laku yang menunjukkan ketaatan karyawan terhadap peraturan organisasi.

\section{METODE PENELITIAN}

Penelitian merupakan kegiatan yang dilakukan untuk mendapatkan kebenaran atau fakta, yang dilakukan dengan mengumpulkan dan menganalisis data secara teliti, 
jelas, serta sistematis, dan dapat dipertanggung jawabkan atau dapat diuji kebenarannya Ferdinand, (2006). Untuk itu dalam proses penelitian perlu menggunakan metode yang biasa disebut metode penelitian.

Populasi adalah wilayah generalisasi yang meliputi obyek atau subyek yang mempunyai kualitas dan karakteristik tertentu yang ditetapkan oleh peneliti untuk dipelajari dan kemudian ditarik kesimpulan Sugiyono, (2015:92). Populasi dalam penelitian ini adalah seluruh karyawan PT Mitratani Dua Tujuh Jember. Sampel adalah bagian dari jumlah dan karakteristik yang dimiliki oleh populasi. Bila populasi besar, dan peneliti tidak mungkin mempelajari semua yang ada pada populasi, misalnya karena keterbatasan dana, tenaga, dan waktu, maka peneliti dapat menggunakan sampel yang diambil dari populasi itu (Sugiyono,2015:93). Dalam penelitian ini populasi yang digunakan adalah karyawan PT Mitratani Dua Tujuh Jember dengan jumlah karyawan 1.654 karyawan, dan kesalahan yang ditolerin adalah $10 \%$. Pengambilan sampel menggunakan Rumus Slovin, dan didapat jumlah sampel sebanyak 94 responden.

\section{Uji Validitas dan Uji Reliabilitas}

Uji Validitas didefinisikan sebagai ukuran seberapa kuat suatu alat tes melakukan fungsi ukurannya. Model pengujian menggunakan pendekatan. Pearson Correlation untuk menguji validitas pernyataan kuesioner. Uji validitas digunakan untuk mengukur sah atau tidaknya suatu kuesioner. Reliabilitas adalah alat untuk mengukur suatu kuesioner yang merupakan indikator dari variabel. Suatu kuesioner dikatakan reliabel atau handal jika jawaban seseorang terhadap pertanyaan adalah konsisten atau stabil dari waktu kewaktu (Ghozali, 2011).

\section{Analisis Regresi linear Berganda}

Regresi bertujuan untuk menguji hubungan pengaruh antara satu variabel terhadap variabel lain. Variabel yang dipengaruhi disebut variabel tergantung atau dependen, sedangkan variabel yang mempengaruhi disebut variabel bebas atau variabel independen Nugroho, (2005). Analisis Regreasi Linier Berganda : $\mathrm{Y}=\mathrm{a}+\mathrm{b} 1 \mathrm{X} 1+\mathrm{b} 2 \mathrm{X} 2+\mathrm{e}$

\section{HASIL DAN PEMBAHASAN}

\section{Hasil Analisis Diskriptif}

Berdasarkan hasil perhitungan dapat diketahui bahwa responden yang berumur 20 sampai 25 tahun berjumlah 8 karyawan atau 8,5\% umur 26-30 tahun berjumlah 23 
karyawan atau 24,5\% umur 31-35 tahun berjumlah 13 karyawan atau 13,8\% umur 26-40 berjumlah 31 karyawan atau 33,0\% umur lebih dari 40 tahun berjumlah 19 karyawan atau 20,2\% dari total responden yang berjumlah 94 karyawan.

Berdasarkan hasil perhitungan diskriptif atas dasar jenis kelamin dapat diketahui bahwa responden yang berjenis kelamin perempuan berjumlah 67 orang atau 71,7\%, dan responden yang berjenis kelamin laki-laki berjumlah 27 orang atau 28,3\% dari total responden yang berjumlah 94 karyawan.

Berdasarkan hasil perhitungan statistic responden atas dasar pendidikan dapat diketahui bahwa responden yang pendidikan Diploma ada 3 karyawan atau 3,2\% dan yang berpendidikan SMA ada 91 karyawan atau 96,8\% dari total responden yang berjumlah 94 karyawan.

Berdasarkan hasil perhitungan atas dasar lama bekerja dapat diketahui bahwa responden yang bekerja selama 1- 5 tahun berjumlah 25 karyawan atau 26,6\% bekerja selama 6-10 tahun berjumlah 17 karyawan atau 18,1\% bekerja selama lebih dari 10 tahun berjumlah 50 karyawan atau 53,2\% dari total responden yang berjumlah 94 karyawan.

\section{Uji Validitas}

Uji validitas digunakan untuk mengukur sah atau valid tidaknya suatu kuisioner. Suatu kuesioner dikatakan valid jika pertanyaan pada kuisioner mampu untuk mengungkap sesuatu yang akan di ukur oleh kuisioner tersebut (Ghozali, 2011). Hasil perhitungan statistic terkit uji validitas menunjukkan terlihat bahwa korelasi antara masing-masing indikator terhadap total skor konstruk dari setiap variabel menunjukkan hasil yang valid, karena $r_{\text {hitung }}>r$ tabel dan nilai signifikansi $<0,05$. Sehingga dapat disimpulkan bahwa semua item pernyataan dinyatakan valid.

\section{Uji Reliabilitas}

Reliabilitas adalah alat untuk mengukur suatu kuesioner yang merupakan indikator dari variabel.Suatu kuesioner dikatakan reliable atau handal jika jawaban seseorang terhadap pertanyaan adalah konsisten atau stabil dari waktu kewaktu (Ghozali, 2011). Hasil uji reliabilitas tersebut menunjukkan bahwa semua variabel mempunyai koefisien alpha yang cukup atau memenuhi kriteria untuk dikatakan reliabel yaitu di atas 0,600, sehingga untuk selanjutnya item-item pada masing-masing konsep variabel tersebut layak digunakan sebagai alat ukur. 


\section{Analisis Regresi Linier Berganda}

Regerai bertujuan untuk menguji hubungan antara satu variabel terhadap variabel lain. Variabel yang dipengaruhi disebut variabal tergantung atau dependent, sedangkan variabel yang mempengaruhi disebut variabel bebas atau variabel independent (nugroho.2005). Analisis Regresi Linear Berganda:

\section{Tabel 2:.Hasil Analisis Regresi Linier Berganda}

\begin{tabular}{clcc}
\hline No & \multicolumn{1}{c}{ Variabel } & Koefisien Regresi & Signifikansi \\
\hline 1 & Kinerja Karyawan & 4,363 & 0,000 \\
\hline 2 & Lingkungan Kerja $\left(\mathrm{X}_{1}\right)$ & 0,228 & 0,001 \\
\hline 3 & Kakarteristik Individu $\left(\mathrm{X}_{2}\right)$ & 0,287 & 0,000 \\
\hline 4 & Disiplin Kerja $\left(\mathrm{X}_{3}\right)$ & 0,387 & 0,000 \\
\hline Sumber: Data Diolah & &
\end{tabular}

\section{Uji t}

Hipotesis dalam penelitian ini diuji kebenarannya dengan menggunakan uji parsial. Pengujian dilakukan dengan melihat statistik $\mathrm{t}$ hitung dengan nilai statistik $\mathrm{t}$ tabel dan taraf signifikansi ( $p$-value), jika taraf signifikansi yang dihasilkan dari perhitungan di bawah 0,05 maka hipotesis diterima, sebaliknya jika taraf signifikansi hasil hitung lebih besar dari 0,05 maka hipotesis ditolak (Ghozali, 2013:97). Nilai $\mathrm{t}_{\text {tabel }}$ didapatkan dari $\mathrm{df}=\mathrm{n}-\mathrm{k}$ (55-4) sama dengan 51. Dimana $\mathrm{n}$ adalah jumlah sampel dan $\mathrm{k}$ adalah jumlah variabel penelitian. Jadi untuk melihat $\mathrm{t}_{\text {tabel }}$ caranya dengan melihat tabel $\mathrm{t}$ baris ke 51 yaitu 1.6753 .

Tabel 3: Hasil Uji t

\begin{tabular}{llccccc}
\hline \multirow{2}{*}{ No } & Variabel & \multicolumn{4}{c}{ Item Uji } & Keterangan \\
\cline { 3 - 5 } & & $\begin{array}{c}\text { Signifikansi } \\
\text { Hitung }\end{array}$ & $\begin{array}{c}\text { Taraf } \\
\text { Signifikansi }\end{array}$ & $\mathbf{t}_{\text {hitung }}$ & $\mathbf{t}_{\text {table }}$ & Signifikan \\
\hline 1 & Lingkungan kerja & 0,001 & 0,05 & 3.282 & 1.661 & Signiknifian \\
2 & Karakteristik Individu & 0,000 & 0,05 & 2.808 & 1.661 & Signifikan \\
3 & Disiplin kerja & 0,000 & 0,05 & 2.374 & 1.661 & Signifikan \\
\hline
\end{tabular}

Sumber: Data Diolah

\section{Koefisien Determinasi $\mathbf{R}^{2}$}

Koefisien determinasi merupakan besaran yang menunjukkan besarnya variasi variabel dependen yang dapat dijelaskan oleh variabel independennya. Dengan kata lain, koefisien determinasi ini digunakan untuk mengukur seberapa jauh variabel-variabel bebas dalam menerangkan variabel terikatnya. 
Tabel 4. Hasil Uji Koefisien Determinasi

\begin{tabular}{llc}
\hline No & \multicolumn{1}{c}{ Kriteria } & Koefisien \\
\hline 1 & $R$ & 0,857 \\
2 & $R$ Square & 0,735 \\
3 & Adjusted $R$ Square & 0,726 \\
\hline
\end{tabular}

Sumber: Data Diolah

Hasil perhitungan regresi pada tabel 4. dapat diketahui bahwa koefisien determinasi yang diperoleh sebesar 0,726 . Hal ini berarti 72,6\% variasi variabel kinerja karyawan dapat dijelaskan oleh lingkungan kerja, karakteristik individu dan disiplin kerja, sedangkan sisanya sebesar 0,274 atau 27,4\% diterangkan oleh variabel lain diluar model atau persamaan seperti menambah variabel kompensasi dan kompetensi.

\section{Pembahasan}

Secara nyata berdasarkan hasil penelitian menunjukan bahwa secara statistik kedua hipotesis yang diajukan mendukung teori dan hipotesis yang diajukan. Berdasarkan hasil pengujian secara statistik, penjelasan dari masing-masing pengaruh variabel dijelaskan sebagai berikut:

a. Hasil pengujian membuktikan lingkungan kerja mempunyai pengaruh terhadap kinerja karyawan. Artinya bahwa lingkungan kerja yang meliputi penerangan, suara bising, keamanan kerja dll berpengaruh terhadap kinerja karyawan. Menurut Mangkunegara (2004), lingkungan kerja mempunyai hubungan yang sangat erat terhadap kinerja karyawan, motif berprestasi yang perlu dimiliki oleh karyawan harus ditumbukhan dari dalam diri sendiri dan lingkungan kerja, karena motif berprestasi yang ditumbuhkan dari dalam diri sendiri akam membentuk suatu kekuatan diri dan jika situasi lingkungan kerja turut menunjang maka pencapaian kinerja akan lebih mudah. Dengan taraf signifikasi 0,001 atau lebih kecil dari 0,05. Hasil ini juga mendukung penelitian sebelumnya oleh Setiawan (2013). Dalam penelitian ini dalam menganalisis data menggunakan analisis regresi linier berganda. Hasil dari penelitian ini adalah variabel lingkungan kerja berpengaruh positif dan signifikan terhadap kinerja karyawan.

b. Hasil pengujian membuktikan bahwa karakteristik individu mempunyai pengaruh terhadap kinerja karyawan. Artinya bahwa karakteristik individu yang meliputi watak, usia karyawan, dan hubungan karyawan mempengaruhi kinerja karyawan. Simamora, (2004) bahwa karakteristik individu adalah keinginan,sikap dan kebutuhan 
seseorang yang dibawa kedalam situasi kerja. Suatu perusahaan bagaimanapun majunya teknologi yang dimiliki tanpa ditunjang dengan dan oleh tenaga kerja yang cakap maka kemungkinan besar sasaran dari perusahaan tidak akan tercapai. Tenaga kerja yang bekerja sesuai dengan fungsinya (the right man in the right place) akan menunjang tercapainya keberhasilan tujuan perusahaan. Dengan taraf signifikasi 0,000 atau lebih kecil dari 0,05 maka variabel komitmen organisasi dipertahankan guna meningkatkan kinerja karyawan. Hasil ini juga mendukung penelitian sebelumnya oleh Saputra (2017). Dalam penelitian ini dalam menganalisis data menggunakan analisis regresi linier berganda. Hasil dari penelitian ini adalah variabel karakteristik individu berpengaruh positif dan signifikan terhadap kinerja karyawan.

c. Hasil pengujian membuktikan bahwa disiplin kerja mempunyai pengaruh terhadap kinerja karyawan. Artinya bahwa kedisiplinan yang meliputi Ketaatan dalam kehadiran kerja, ketaatan aturan pakaian kerja, ketaatan pada prosedur kerja, etika dalam bekerja. Pegawai yang mempunyai disiplin akan menaati peraturan yang ada pada lingkungan kerjanya dengan kesadaran yang tinggi tanpa ada paksaan. Kedisiplinan adalah kesadaran dan kesediaan seseoarang dalam mentaati semua peraturan organisasi dan norma sosial yang berlaku (Hasibuan, (2002:193). .Dengan taraf signifikasi 0,000 atau lebih kecil dari 0,05 maka variabel kedisiplinan dipertahankan guna meningkatkan kinerja karyawan. Hasil ini juga mendukung penelitian sebelumnya oleh Triyaningsih (2014). Dalam penelitian ini dalam menganalisis data menggunakan analisis regresi linier berganda. Hasil dari penelitian ini adalah variabel disiplin kerja berpengaruh positif dan signifikan terhadap kinerja karyawan.

\section{KESIMPULAN DAN SARAN}

\section{Kesimpulan}

Dari pengujian secara statistic yang telah dilakukan, maka dapat ditarik kesimpulan sebagai berikut:

a. Lingkungan kerja berpengaruh positif dan signifikan terhadap kinerja karyawan PT. Mitratani Dua Tujuh Jember. Hal ini menunjukkan apabila lingkungan kerja baik maka kinerja karyawan semakin baik, sebaliknya jika lingkungan kerja tidak baik maka kinerja karyawan akan menurun. 
b. Karakteristik individu berpengaruh secara positif dan signifikan terhadap kinerja karyawan PT. Mitratani Dua Tujuh Jember. Hal ini menunjukkan apabila karakteristik individu yang dimiliki karyawan baik maka kinerja karyawan akan semakin baik.

c. Disiplin kerja berpengaruh secara positif dan signifikan terhadap kinerja karyawan Universitas Muhammadiyah Jember. Hal ini menunjukkan apabila tingkat kedisiplinan meningkat maka kinerja karyawan akan meningkat

Hasil perhitungan regresi pada tabel 4.16 dapat diketahui bahwa koefisien determinasi yang diperoleh sebesar 0,726.. Hal ini berarti 72,6\% variasi variabel kinerja karyawan dapat dijelaskan oleh lingkungan kerja, karakteristik individu dan disiplin kerja, sedangkan sisanya sebesar 0,425 atau 42,5\% diterangkan oleh variabel lain diluar model atau persamaan seperti menambah variabel kompensasi dan kompetensi.

\section{Saran}

\section{Bagi perusahaan}

Berdasarkan dari hasil pembahasan pada bab sebelumnya dan kesimpulan yang telah diterapkan diatas, maka penulis dapat memberikan beberapa saran khususnya kepada pihak PT. Mitratani Dua Tujuh Jember yaitu:

a) Diharapkan PT. Mitratani Dua Tujuh Jember dapat mempertahankan dan memperbaiki lingkungan kerja seperti penerangan, ruang gerak, kemananan kerja dll ,agar karyawan dapat bekerja dengan nyaman.

b) Diharapkan PT. Mitratani Dua Tujuh Jember dapat mempertahankan dan memperbaiki karakteristik individu seperti pendidikan, watak dan perilaku karyawan yang baik agar karyawan mempunyai hubungan yang baik dengan karyawan lain

c) Diharapkan PT. Mitratani Dua Tujuh Jember dapat mempertahankan dan memperbaiki disiplin kerja pada karyawan agar tidak terdapat karyawan yang masih banyak karyawan yang tidak masuk kerja tanpa alasan.

\section{Bagi peneliti selanjutnya}

Dan diharapkan pada peneliti selanjutnya agar diperluas dan lebih dalam dengan menambah objek atau variabel lingkungan kerja dan karakteristik individu agar dapat gambaran yang lebih lengkap sehingga penelitian yang akan datang lebih sempurna dari penelitian ini. 


\section{DAFTAR PUSTAKA}

Arikunto S, 2006. Prosedur Penelitian Suatu Pendekatan Praktik, Ed Revisi VI, Penerbit PT Rineka Cipta, Jakarta.

Azhad, M. Naely , Anwar, Nurul Qomariah. 2015. Manajemen Sumberdaya Manusia. Jember. Cahaya Ilmu.

Benardin, H. John, dan Joyce EA Russel. (2003). Human Resource Manajemen.(An Experimental Approach International Edition). Mc. Graw-Hill Inc. Singapore.

Efendy, 2012. Metode Penelitian Survei.Jakarta:LP3ES.

Fathoni , 2006, Manajemen Sumber Daya Manusia, Bandung : Rineka Cipta.

Ferdinand, Augusty.2006. Metode Penelitian Manajemen Edisi 2. Semarang: BP Universitas Diponegoro.

Ghozali, Imam.2011. Aplikasi Analisis Multivaria Dengan Prgram SPSS.Semarang: Badan Penerbit Universitas Diponegoro.

Hasibuan, Melayu SP. 2005. Manajemen Sumber Daya Manusia. Edisi Revisi.

Bumi Aksara, Jakarta.

Handoko, T, Hani. 2008. Manajemen Personalia dan Sumber Daya Manusia, Edisi Kedua.Yogyakarta : BPFE.

Mangkunegara, Anwar Prabu. 2005. Manajemen Sumber Daya Manusia. Evaluasi Kinerja. Bandung. PT. Remaja Rosda Karya.

Nawawi. 2013. Budaya organisasi kempemimpinan dan kinerja. Jakarta: PT. Fajar Interpratama Mandiri.

Nitisemito, Alex S. 2005. Manajemen Personalia: (Manajemen Sumber Daya Manusia), Edisi Keempat belas, Ghalia Indonesia, Jakarta.

Nitisemito, 2008. Manajemen Personalia, Ghalib Indonesia, Jakarta.

Nursalam, 2008. Konsep dan Penerapan Metodologi Penelitian Ilmu Keperawatan : Jakarta: Salemba Medika.

Ranupandojo, H., dan Suad Husnan, 2002, Manajemen Personalia, Yogyakarta: BPFE.

Rivai, 2011. Manajemen Sumber Daya Manusia untuk Perusahaan: dari Teori ke Praktik, Jakarta : RajaGrafindo Persada. 
Rochaety E, dkk. 2007. Metodologi Penelitian Bisnis : Dengan Aplikasi SPSS, Edisi Pertama Penerbit Mitra Wacana Media, Jakarta.

Saputra. 2017. Lingkungan Kerja dan Karakteristik Individu Terhadap Kinerja Karyawan ( Pada Hotel Ratu Mayang Garden Pekanbaru) Jurnal Fisip Vol.4 No: 2

Sedarmayanti, 2009, Sumber Daya Manusia dan Produktivitas Kerja, Bandung: CV,Mandar Maju.

Sedarmayanti. (2011) Manajemen Sumber Daya.Reformasi Birokrasi dan Manajemen Pegawai Negeri Sipil (cetakan kelima).

Bandung: PT Refika Aditama.

Setiawan, 2013. Pengaruh Karakteristik Individu dan Lingkungan Kerja Terhadap Kinerja Karyawan pada PT. AWETAMA BINA REKSA. Jurnal AKMENBISP Permata Harapan Vol.II No:01.

Siagian, Sondang. P. 2006. Sistem Informasi Manajemen. Jakarta: PT. Bumi Aksara

Simamora,H. 2004 Manajemen Sumber Daya Manusia. Edisi Ketiga. Yogyakarta: Sekolah Tinggi Ilmu Ekonomi YKPN.

Singodimedjo, Markum. (2000). Manajemen Sumber Daya Manusia. Surabaya : SMMAS.

Siswanto Sastrohadiwiryo, 2003. Manajemen Tenaga Kerja Indonesia, Pendekatan Administrasi dan Operasional. Jakarta : Bumi Aksara.

Sondang P. Siagian. 2011. Manajemen Sumber Daya Manusia, Jakarta: PT. Bumi Aksara.

Subagiarto. 2016. Lingkungan Kerja dan Karakteristik Individu Terhadap Kinerja Karyawan Dengan Kesehatan Kerja Sebagai Variabel Inventering (Pada Pelayanan Perijinan Terpadu Satu Pintu dan Penanaman Modal Kota Denpasar) Jurnal Manajemen \& Bisnis. Vol.13. No:3.

Suyadi P., 1999, Manajemen Sumber Daya Manusia: Kebijakan Karyawan, Edisi Pertama, Cetakan Pertama, Yogyakarta: BPFE UGM.

Sulastiningsih, 2014, Pengaruh Lingkungan Kerja, Karakteristik Individu dan Motivasi Kerja Terhadap Kinerja Karyawan (studi kasus pada Dinas Pendidikan Kabupaten Purworejo) jurnal Kajian Bisnis Vol.22 No:01.

Sugiyono. 2004. Metode Penelitian Bisnis. Bandung: CV. Alfabeta. Sugiyono. 2002. Statistik Penelitian; Alfabeta, Bandung. . 2015. Statistik Non Parametis Untuk Penelitian. Penerbit Alfabeta : Bandung. 
Alfabeta.

Sutrisno, Edi, 2009. Manajemen Sumber Daya Manusia Edisi Pertama. Jakarta: Kencana Prenada Media Group.

Supranto, 2008. Statistik Teori dan Aplikasi. Jakarta: Penerbit Erlangga.

Thoha, Miftah. 2008. Perilaku Organisasi : Konsep Dasar dan Aplikasinya. Jakarta: Raja Grafindo Persada.

Triyaningsih, SL. 2014. Analisis Pengaruh Disiplin Kerja, Motivasi Kerja dan Komitmen Organisasi Terhadap Kinerja Karyawan. Universitas Slamet Riyadi Surakarta. Informatika edisi September 2014 Vol 1. No.2 : 31-38.

Wibowo. 2010. “Manajemen Kinerja; Edisi Ketiga”. PT. Raja Grafindo Prasada: Jakarta. 